\title{
ANALISIS PERBANDINGAN METODE PENINGKATAN WEAR RESISTANCE
}

\author{
Nurdin Hasananto \\ Jurusan Teknik Mesin Universitas Brawijaya Malang \\ 081913815366 \\ E-mail: nurdinhasananto@gmail.com
}

\begin{abstract}
Improving wear resistance has many variated techniques. The purpose of this work is to compare between DCT (Deep Cryogenic Treated) technique and sand blasting treatment on material steel. XRD ,SEM and TEM are used to examine the changing phase in microstructure level and Hardness contact zones after and before testing. Hence, it can be defined which method that improve significantly the wear resistance.
\end{abstract}

Keywords: DCT, Sand Blasting, XRD, SEM, TEM .

\section{PENDAHULUAN}

Seiring berkembangnya teknologi di dalam dunia industri, tuntutan akan service life yang tinggi dan biaya rendah menjadi salah satu yang di tekankan. Berbagai cara dilakukan dalam pengembangan sifat mekanik dari material yang di pakai seperti wear resistance,perubahan fase mikrostruktur, coating, dan fatigue .Pada penelitian kali ini wear resistance dan kekerasan menjadi tolak ukur.Wear resistance adalah fungsi dari beberapa sifat material (kekerasan, kekuatan, dII), friksi serta pelumasan[1].Metode yang bisa digunakan untuk meningkatkan wear resistance adalah DCT dan Sandblasting.

Deep cryogenic treatment (DCT) adalah proses perlakuan spesiment pada suhu cryogenic ( -190 derajat celcius ).Proses ini bertujuan untuk meningkatkan wear resistance dan mengurangi residual stress[2].DCT ini menggunakan nitrogen cair dalam mencapai suhu kerja.Dalam pengembangannya,metode DCT ini dapat meningkatkan ketahanan korosi dengan penambahan carbida pada permukaan material.

Sandblasting adalah proses penyemprotan abrasive material biasanya berupa pasir silika atau steel grit dengan tekanan tinggi pada suatu permukaan untuk meningkatkan kekerasan tertentu.Tingkat kekerasan dapat disesuaikan dengan ukuran pasirnya serta tekanannya.

Kedua metode ini akan di bandingkan dalam meningkatkan wear resistance dari material baja. Perubahan fase dalam skala mikrostruktur diamati dengan menggunakan
Scanning Electron Microscopy (SEM) dan X-ray Diffraction.Perubahan nilai kekerasan akan di uji pada Brinell Hardness Test. Pengujian wear resistance menggunakan tribometer dengan bola AL2O3 diameter $5 \mathrm{~mm}$.

\section{METODOLOGI PENELITIAN}

Pada material baja akan di gunakan dua metode untuk mendapat perbandingan hasil kenaikan hasil kekerasan dan wear resistance. Untuk proses sandblasting, spesimen akan di bombardir dengan pasir mempunyai kekerasan dan energi yang besar. Kecepatan pasir yang menumbuk pada proses ini mencapai 50-200 $\mathrm{m} / \mathrm{s}$ yang di hembuskan oleh aliran udara.Adapun parameter dari sandblasting yang di pilih : 1) Tekanan dari hembusan udara adalah 0.3 Mpa 2) suhu kerja 23 derajat celcius 3) diameter pasir yang di gunakan 220 mikrometer 4) Lama waktu pengujian adalah 30 menit.

Adapun proses dari Deep Cryogenic Treatment menggunakan parameter : 1) suhu kerja -196 derajat celcius 2) lama waktu pengujian adalah 48 jam 3) Laju pendinginan adalah 3 derajat/menit 4) Pada proses di gunakan laju alir oxygen 200 liter/menit 5) jarak penyemprotan $250 \mathrm{~mm}$

Penelitian ini menggunakan metode komparasi,antar dua proses perlakuan dimana secara garis besar sangatlah berbeda untuk tujuan yang hampir sama yaitu meningkatkan wear resistance. Perbandingan perubahan nilai koefisien gesek dalam bentuk persen. Persentase kenaikan sekecil apapun antar dua proses ini membuat penilaian proses yang 
mana yang lebih efektif dalam mencapai hasil yang diinginkan.

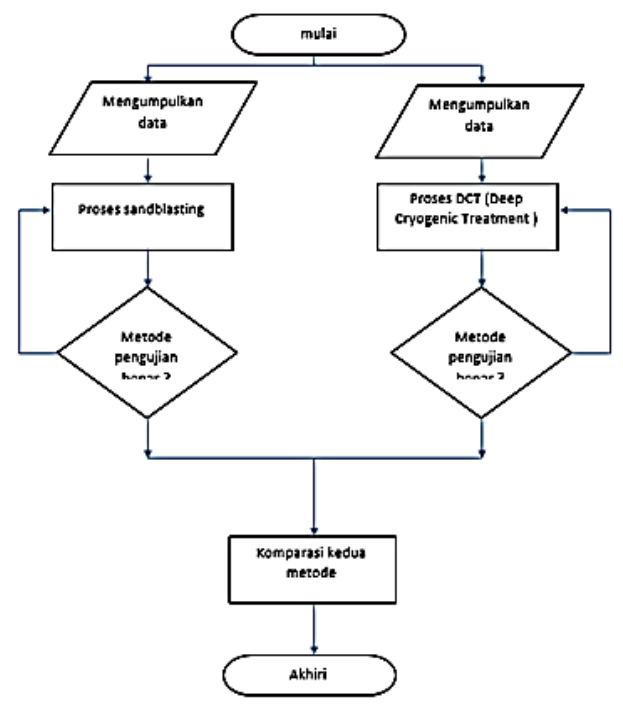

Gambar 1. Flowchart Metode Penelitian [2]

\section{HASIL DAN PEMBAHASAN Pembahasan Grafik}

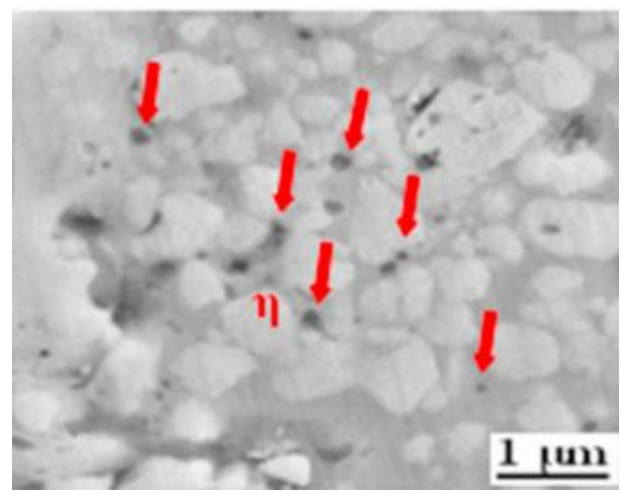

Gambar 2. DCT selama 48 jam [2]

Pada gambar 2 dapat dilihat irisan melintang dari spesimen setelah dilakukan DCT selama 48 jam. Fase $\eta$ adalah fase dari proses tambahan yaitu coating WC (Tungsten Carbide) yang dapat menaikkan kekerasan dan kerapuhan. Fase $\eta$ ini membuat suatu ikatan koheren dari matriks material spesimen. Peningkatan $\eta$ fase pada setelah proses DCT. Selain itu terdapat efek coating dari WC (tungsten carbide) setebal $400 \mathrm{~nm}$.
Pada hasil SEM,setelah dilakukan proses grinding, lebar yang terbentuk setelah proses grinding merepresentasikan wear resistance dari spesimen. Semakin lebar maka nilai dari wear resistance semakin lemah, Parameter lain adalah lamellar spalation. Lamellar spalation dapat ditunjukan pada gambar 3
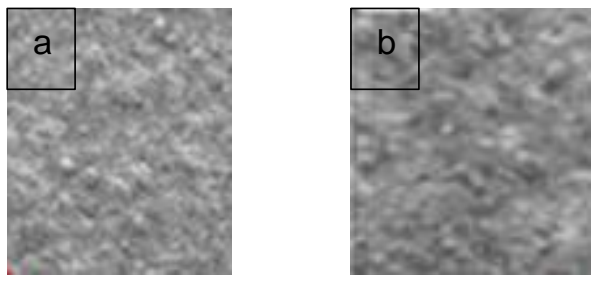

Gambar 3. (a) sebelum DCT (b) setelah DCT

[2]

Semakin banyak garis lamillar spalation menandakan sifat Anti-Wear.Pada permukaan spesimen sebelum perlakuan DCT ( gambar 3a ) menunjukan adanya lamellar spallation yang sangat jelas. Mengindikasikan gaya binding yang lemah dan wear resistance.Dibandingkan dengan yang tidak dilakukan perlakuan,lamillar spallation pada spesimen telah berkurang secara signifikan

Sifat mekanis dari tungsten carbida membantu proses DCT dengan meningkatkan $\eta$ fase dan $\varepsilon$-CO. Pada penurunan temperatur di proses DCT,membuat kisaran Gibbs Free Energy antara $\alpha$ dan $\varepsilon$ fase dari CO. Semakin turun temperatur maka semakin besar range antar kedua energi dari dua fase ini dan membentuk $\eta$ fase. $\eta$ fase merupakan fase yang tidak sempurna dari coating WC.biasa berukuran $200 \mathrm{~nm}$ seperti di tunjukan pada panah gambar $2 . \eta$ fase ini meningkatkan kekerasan dan kerapuhan

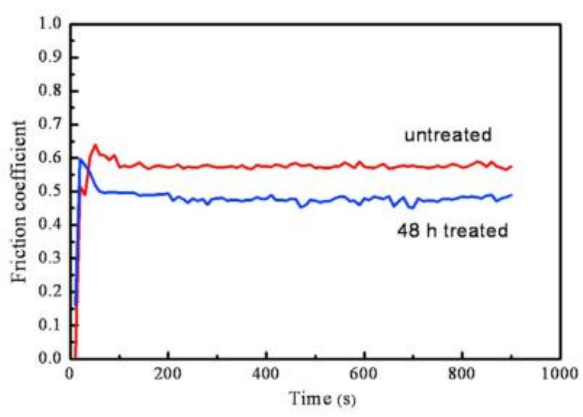

Gambar 4. koefisien gesek sebelum dan sesudah proses DCT 48 jam[2] 
Lamanya proses DCT membuat nilai koefisien gesek dari spesimen berubah seperrti pada gambar 4.Terjadi penurunan setelah dilakukan proses ini. Koefisienn gesek berkaitan dengan wear resistance dan kekasaran permukaan. Semakin rendah nilai dari koefisien gesek maka semakin kuat wear resistance dari spesimen tersebut.Sebaliknya, semakin tinggi koefisien gesek dari spesimen maka semakin rendah ketahanan dari wear resistancenya.

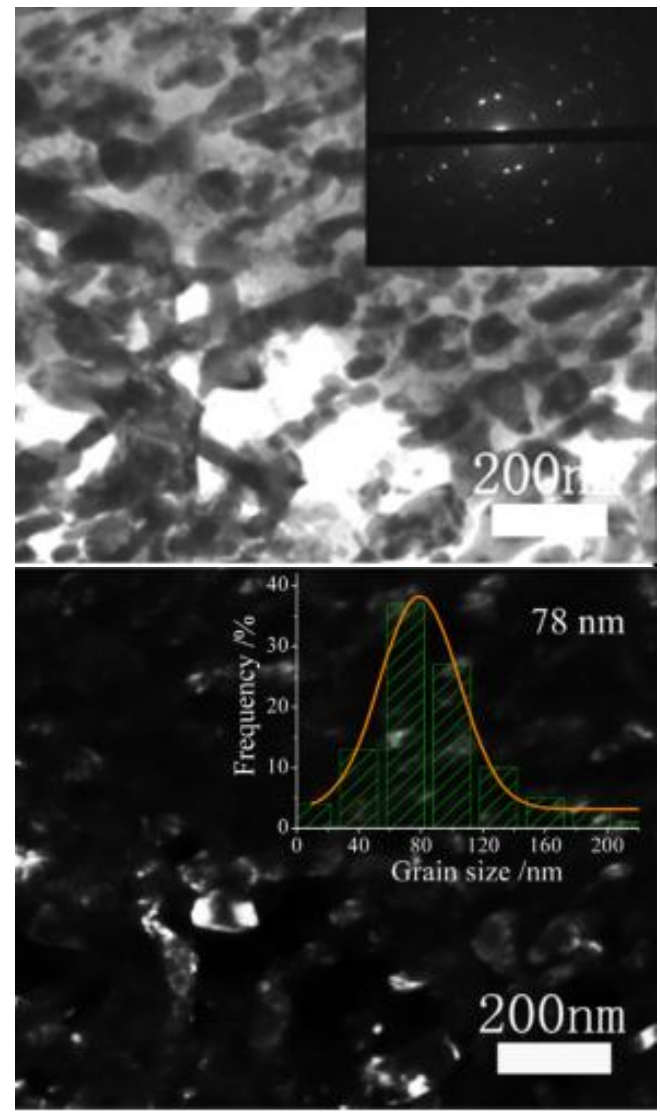

Gambar 5. (a) zona terang (b) zona gelap berdasarkan TEM [1]

Pada proses sandblasting spesimen di amati pada TEM ( Transmision Electron Microscopy). Ukuran rata rata dari butir sekitar $78 \mathrm{~nm}$ yang dapat kita lihat pada gambar 5b. Berdasarkan SAED ( Semi Auto Eksternal Defibrilation ) terindikasikan pembentukan nanocrystallization pada permukaan,yang tersusun atas ferite dan cementite (3). Zona terang atau bright field merupakan mode yang paling sering digunakan dalam penggunaan
TEM.Pada mode ini semakin tebal atau semakin tinggi nomor atom maka semakin gelap hasilnya.Zona gelap dan terang berdasarkan oleh Hukum Beer's Lambert [2] :

$$
T=\frac{\Phi_{\mathrm{e}}^{\mathrm{t}}}{\Phi_{\mathrm{e}}^{\mathrm{i}}}
$$

Dimana :

$$
\begin{aligned}
& \Phi_{\mathrm{e}}^{\mathrm{t}}=\text { jumlah raddiant flux yang di berikan } \\
& \Phi_{\mathrm{e}}^{\mathrm{i}}=\text { jumlah raddiant flux yang di terima }
\end{aligned}
$$

Pada proses sandblasting ini memberikan beban kejut yang berulang pada permukaan material.Pada lapisan atas, terjadi deformasi yang besar akibat dari sand blasting.Nilai kisaran dari strain rate $1000-10000 / \mathrm{s}$ pada bagian atas,dan semakin berkurang dengan bertambahnya tebal dari material.Semakin tinggi strain rate diimbangi dengan perubahan kerapatan yang besar

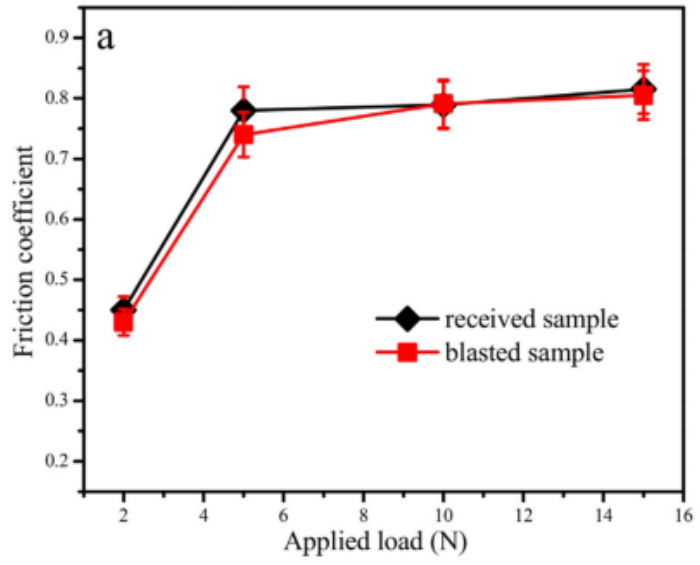

Gambar 6. koefisien gesek spesimen setelah dan sebelum sandblasting [1]

Koefisien gesek rata rata dari spesimenn setelah di lakukan pengujian dapat dilihat pada gambar 6.Perubahann koefisien gesek sudah terjadi pada pembebanan paling kecil. Kekerasan dari permukaan di cari menggunakan micro indenter probe.Perubahan kekerasan permukaan yang sebelumnya berada di nilai 3.3 Gpa naik menjadi 5.5 Gpa. Perubahan kekerasan ini di ikuti dengan perubahan kedalaman dari spesimen antara $20 \mu \mathrm{m}-30 \mu \mathrm{m}$ 
Tabel 1. Perbandingan antara DCT dan sandblasting

\begin{tabular}{|c|l|l|}
\hline NO & \multicolumn{1}{|c|}{ DCT } & \multicolumn{1}{|c|}{ Sandblasting } \\
\hline 1 & $\begin{array}{l}\text { Energi yang di } \\
\text { butuhkan selama } \\
\text { proses 48 jam } \\
\text { sangat besar }\end{array}$ & $\begin{array}{l}\text { Energi yang di } \\
\text { butuhkan lebih } \\
\text { rendah dari pada } \\
\text { DCT }\end{array}$ \\
\hline 2 & $\begin{array}{l}\text { Kenaikan wear } \\
\text { resistance lebih } \\
\text { besar dari pada } \\
\text { sandblasting }\end{array}$ & $\begin{array}{l}\text { Kenaikan wear } \\
\text { resistance lebih } \\
\text { rendah dari pada } \\
\text { proses DCT }\end{array}$ \\
\hline 3 & $\begin{array}{l}\text { Terdapat } \\
\text { kemungkinan } \\
\text { terjadinya thermal } \\
\text { shock ketika laju } \\
\text { pendinginan tidak } \\
\text { di kontrol }\end{array}$ & $\begin{array}{l}\text { Terdapat seleksi } \\
\text { akan kualitas dan } \\
\text { diameter pasir } \\
\text { yang di gunakan }\end{array}$ \\
\hline 4 & $\begin{array}{l}\text { Terdapat proses } \\
\text { tambahan yaitu } \\
\text { coating oleh WC }\end{array}$ & $\begin{array}{l}\text { Tidak terdapat } \\
\text { proses tambahan }\end{array}$ \\
\hline
\end{tabular}

Perbandingan kedua perlakuan antara DCT dan sandblasting dapat di bandingkan melalui koefisien gesek sebelum dan sesudah pengujian.Pada proses DCT perubahan koefisien gesek lebih signifikan dari pada proses sandblasting.Lebih besarnya perubahan DCT dapat dikarenakan karena efek dari coating tambahan dari tungsten carbida sebelum proses DCT dan semakin maksimal ketika proses cryogenic membentuk lebih banyak $\eta$ fase pada spesimen

\section{KESIMPULAN}

Pada pengujian ini di dapat kesimpulan sebagai berikut :

1. Proses Deep Cryogenic treatment dan sandblasting sama sama berhasil menaikkan nilai dari wear resistace

2. Proses DCT lebih efektif dalam menaikan nilai dari wear resistance

\section{DAFTAR PUSTAKA}

[1] Rongpeng,Lical Fui,Lingping Zhou, 2015, Improved wear resistance by phase transformation of surface by sandblasting technique,China

[2] Gang wang,Kaixun Gu, Zhongjia Huang, Pengfei Ding, 2016, Improving the wear resistance of as sprayed WC coating by Deep Cryogenic Treatment, China

[3] Ting Ting wu,Jian Zhou, Bolin, Effect od rare earth media Lu2O3 on the wer resistance for grinding media

[4] S.A Kusmanov, A.A Smirnov, S.A Silikin, P.N Belkin, Increasing wear and corrosion resistance of low-alloy steel, 2014, Russia

[5] Enkyung Lee,Brajendra Mishra, Bruce R.Effect of Heat Treatment on wear resistance, 2016, Qatar 